Застрожнікова Ірина Володимирівна, доктор економічних наук, доцент, доцент кафедри менеджменту та адміністрування Бердянського державного педагогічного університету Запорізька область, м.Бердянськ, вул. Шмідта, 4, 0669595893, e-mail: irenazast@gmail.com, https//orcid.org/0000-0002-9988-5288.

Безугла Людмила Сергіївна, доктор економічних наук, доцент, професор кафедри маркетингу, Національний технічний університет «Дніпровська політехніка», 49000, м. Дніпро, пр. Дм. Яворницького, 19, e-mail: milabezugla@gmail.com, https//orcid.org/0000-0002-6520-4325.

\title{
КОНЦЕПЦІЯ ЦИФРОВІЗАЦІЇ СУЧАСНОЇ ОСВІТИ, ЯК ОСНОВА РОЗВИТКУ КАДРОВОГО ПОТЕНЦІАЛУ ВИРОБНИЧОГО СЕКТОРУ ЕКОНОМІКИ
}

Анотація. Сучасні процеси цифровізації набирають значного прискорення 3 року в рік в усіх секторах економіки. У статті зазначено, що перехід на цифрові технології $\epsilon$ одним 3 найважливіших мегатрендів нашого часу. Зараз використовується чимало цифрових технологій, які наразі активно впроваджуються у виробничих та невиробничий сектори економіки України. Основною рушійною силою в активізації інноваційних процесів формування та реалізації стратегічних напрямків виступатимуть кваліфіковані кадри. Зазначено, що на перший план виходить «осучаснення» освіти, основою чого $\epsilon$ iї цифровізація та інтеграція у сучасні digital-технології та інтеграція у світовий освітній простір. Цифрова трансформація освітньої галузі та формування вітчизняного інформаційно-освітнього середовища призведе до підвищення інтелектуальних, творчих здібностей учнів і вдосконалення професійних компетенцій педагогічних працівників, забезпечить широкий доступ до інноваційних освітніх технологій, підвищить інформаційну безпеку в мережах передачі даних. Основними завданнями розвитку інформаційно-комунікаційного середовища освітнього простору є: вдосконалення інформаційно-комунікаційної інфраструктури закладів освіти; розвиток інформаційної системи управління, що забезпечує в режимі реального часу багаторівневий доступ (заклад освіти - район - область - республіка) до інформації, пов'язаної з освітнім процесом, інтеграцію $з$ відомчої статистикою, розробка нормативної бази для іiі функціонування; впровадження в освітній процес інноваційних методик, заснованих на інформаційних технологіях. Кадровий склад виробничого сектору майбутнього повинен мати системне та екологічне мислення, вміти керувати проектами, володіти навичками IT та в деяких професіях - знання іноземних мов. Саме освіта має сприяти розвитку цифрових навичок у здобувачів. На прикладі аграрного сектору розглянуто основні цифрові перетворення та зміни, на які має 
зреагувати сучасна аграрна освіта усіх рівнів. Орієнтація на зміни в управлінні кадровим потенціалом в цифровій економіці змінює практику роботи по прийняттю управлінських рішень. Особливо це стосується освітньої сфери, так як навчальні заклади здатні сприяти соціально-економічному розвитку, тобто бути центрами інноваційного розвитку.

Ключові слова: цифровізація, освіта, кадровий потенціал.

Zastrozhnikova Irina, Doctor of Economics, Associate Professor, Associate Professor of Management and Administration Department in Berdyansk State Pedagogical University, Berdyansk, Schmidta, 4, 0669595893, e-mail: irenazast@gmail.com, https // orcid.org / 0000-0002-9988-5288.

Bezuhla Liudmyla, Doctor of Economics, Associate Professor, Professor of Marketing Department in Dnipro University of Technology. 49000, Dnipro, Dm. Yavornytskoho, 19, e-mail: milabezugla@gmail.com, https //orcid.org/0000-0002-6520-4325.

\section{THE CONCEPT OF DIGITALIZATION OF MODERN EDUCATION AS A BASIS FOR THE DEVELOPMENT OF HUMAN RESOURCES OF THE PRODUCTION SECTOR OF THE ECONOMY}

Abstract. Modern processes of digitalization are gaining significant momentum from year to year in all sectors of the economy. The article states that the transition to digital technologies is one of the most important megatrends of our time. Many digital technologies are currently used, which are currently being actively implemented in the productive and non-productive sectors of Ukraine's economy. The main driving force in the intensification of innovative processes of formation and implementation of strategic directions will be qualified personnel. It is noted that the "modernization" of education comes to the fore, the basis of which is its digitization and integration into modern digital technologies and integration into the world educational space. Digital transformation of the educational sector and the formation of the domestic information and educational environment will increase the intellectual, creative abilities of students and improve the professional competencies of teachers, provide wide access to innovative educational technologies, increase information security in data networks. The main tasks of the development of the information and communication environment of the educational space are: improvement of the information and communication infrastructure of educational institutions; development of information management system that provides real-time multi-level access (educational institution - district region - republic) to information related to the educational process, integration with departmental statistics, development of regulatory framework for its operation; introduction of innovative methods based on information technologies into the educational process. The personnel of the production sector of the future must have a systematic and ecological thinking, be able to manage projects, have IT skills and in some professions - knowledge of foreign languages. It is education that should promote 
the development of digital skills in applicants. The example of the agricultural sector examines the main digital transformations and changes to which modern agricultural education at all levels should respond. Focusing on changes in human resource management in the digital economy is changing the practice of management decisionmaking. This is especially true in the field of education, as educational institutions are able to promote socio-economic development, ie to be centers of innovative development.

Keywords: digitization, education, human resources.

Постановка проблеми. Реформування української економіки, формування сталого розвитку виробничого та невиробничого секторів неможливо без кваліфікованих кадрів. Роль освіти у цьому контексті є вирішальною, при чому на перший план виходить «осучаснення» освіти, основою чого є їі цифровізація та інтеграція у сучасні digital-технології та інтеграція у світовий освітній простір.

Аналіз останніх досліджень і публікацій. Проблеми цифровізації освіти досліджували наступні українські та іноземні автори: О. Глазунова, Л. Діденко, I. Косенко, Н. Морзе, I. Твердохліб, С. Якубов, G. Doran, J. Hwang, J. Hidasi, T. Malon. Проте, дослідження вказаних вчених зосереджені на дослідженні технічного боку smart-освіти. Розробка та аналіз концепції цифровізації освіти потребує подальшого дослідження.

Мета статті - розробка та аналіз концепції цифровізації сучасної освіти, а також вивчення іiі впливу на розвиток кадрового потенціалу виробничого сектору економіки на прикладі аграрного сектору.

Виклад основного матеріалу. Кваліфіковані кадри завжди були і будуть основною рушійною силою в активізації інноваційних процесів формування та реалізації стратегічних напрямків в усіх секторах економіки. Так, наприклад, для забезпечення найважливішої складової функціонування українського суспільства - продовольчої безпеки країни і підвищення конкурентоспроможності на світових ринках одним 3 ключових напрямків інноваційного розвитку сільського господарства має стати його діджиталізація. [3]

Найважливіша умова їі реалізації - це підготовка didgital-аграріїв, які здатні здійснити цифрову цифрову трансформацію сільського господарства за допомогою впровадження цифрових технологій i платформних рішень для забезпечення технологічного прориву в аграрному секторі і досягнення зростання продуктивності праці. У зв'язку 3 цим одним 3 нових напрямків роботи 3 формування кадрового потенціалу аграрного сектору стане підготовка фахівців в області цифрової економіки [3].

Цифровізація освіти - один із пріоритетів МОН розвитку можливостей дистанційного навчання. Тому 3-поміж ключових завдань на 2021 рік $\epsilon$ затвердження Концепції цифрової трансформації освіти і науки, забезпечення закладів освіти цифровою інфраструктурою, Всеукраїнської школи онлайн, модернізація державного електронного журналу та підвищення рівня цифрової компетентності педагогічних працівників.

Цифрова трансформація освітньої галузі та формування вітчизняного 
інформаційно-освітнього середовища призведе до підвищення інтелектуальних, творчих здібностей учнів і вдосконалення професійних компетенцій педагогічних працівників, забезпечить широкий доступ до інноваційних освітніх технологій, підвищить інформаційну безпеку в мережах передачі даних [1].

Основними завданнями розвитку інформаційно-комунікаційного середовища освітнього простору є: освіти;

- вдосконалення інформаційно-комунікаційної інфраструктури закладів

- формування інтегрованої інформаційно-освітнього середовища;

- розвиток інформаційної системи управління, що забезпечує в режимі реального часу багаторівневий доступ (заклад освіти - район - область республіка) до інформації, пов'язаної з освітнім процесом, інтеграцію з відомчої статистикою, розробка нормативної бази для іiі функціонування;

- впровадження в освітній процес інноваційних методик, заснованих на інформаційних технологіях.

Для реалізації поставлених завдань нами було розроблено наступний механізм (рисунок 1).

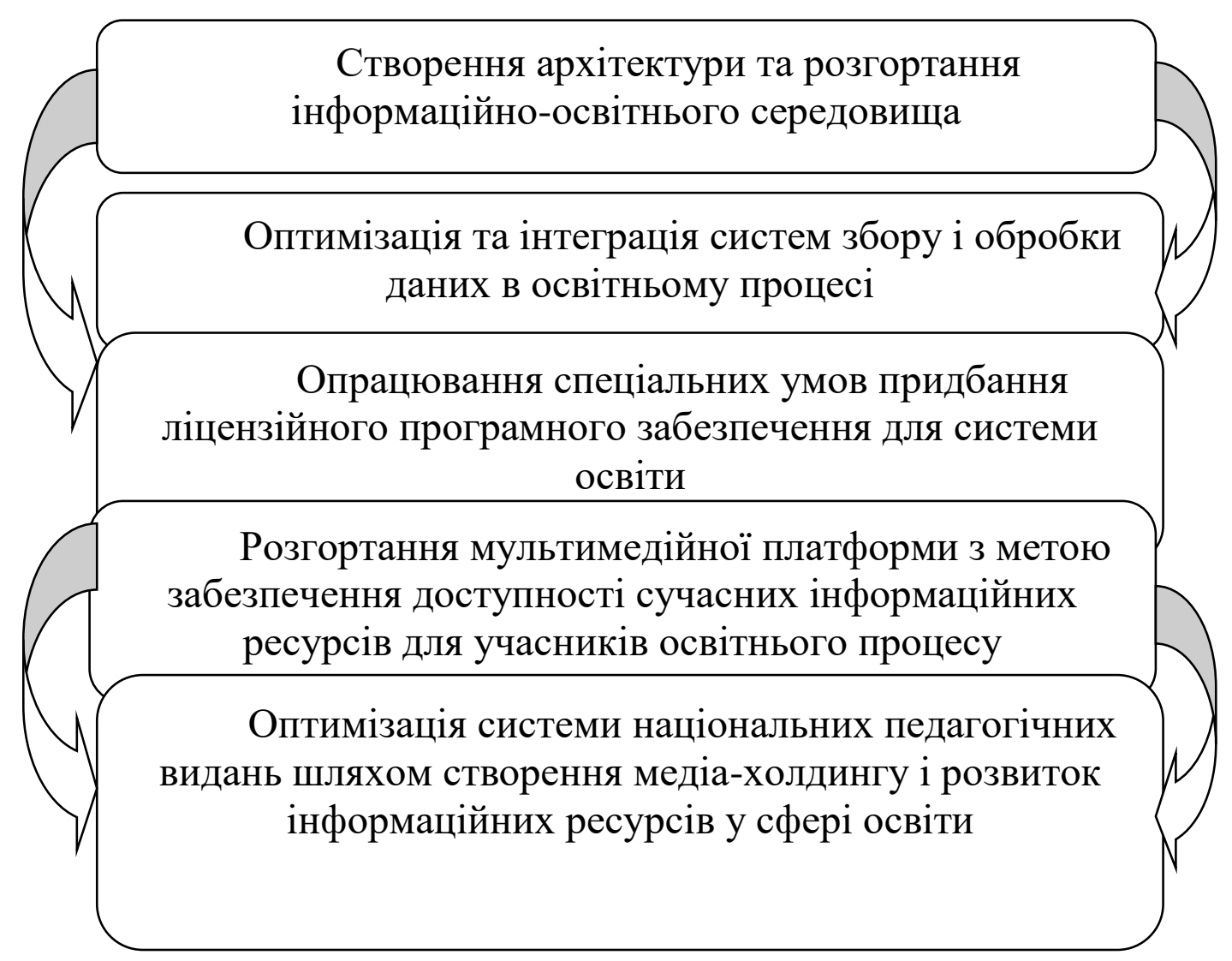

Pис. 1. Механізм реалізаиії завдань для розвитку інформаиійнокомунікаційного середовища освітнього простору

Джерело: розроблено авторами

3 урахуванням використання даного механізму, перспектива розвитку інформаційно-комунікаційного середовища освітнього простору до 2030 року 
виглядає наступним чином:

- розвиток освітніх технологій, інтерактивних засобів навчання, мультимедійної платформи дистанційного надання освітнього контенту;

- формування автоматизованої інформаційно-аналітичної системи збору, зберігання, обробки і аналізу даних, що дозволяє здійснювати ранню діагностику обдарованої молоді, своєчасне визначення наявності талантів або відхилень у розвитку учнів, ідентифікувати негативні або позитивні тренди в педагогічних методиках і освітніх програмах, прогнозувати розвиток освітньої траєкторії як в учнів, так і у педагогічних працівників;

- вдосконалення системи книговидання, включаючи цифровизацію;

- використання інформаційних технологій при проведенні ліцензування освітньої діяльності, державну акредитацію (підтвердження акредитації) закладів освіти.

Автоматизація i функціонування віртуального середовища обумовлюють застосування відповідних підходів до системи управління персоналом підприємства та розвитку його кадрового потенціалу. Розглянемо основні принципи використання цифрових технологій на прикладі аграрного сектору та аграрної освіти. Аграрна освіта усіх рівнів посідає наразі одне з головних місць в системі освіти України.

Відомо, що ринок праці майбутнього визначає, що аграрний сектор входить у п’ятірку галузей, у яких відбудеться у найближчому майбутньому значне заміщення персоналу. Щодо аграрної логістики, то у цій галузі в результаті автоматизації очікується заміщення персоналу на 15\% вже до 2030 року. Деякі трудові процеси вже успішно заміщені діджитал-технологіями в багатьох аграрних підприємствах, особливо у великих агрохолдингах. Так, наприклад, максимально автоматизовані лінії навантаження-розвантаження на сільськогосподарських складах. На деяких полях вже відсутня звичайна охорона, а врожай охороняється за допомогою спеціальних автоматизованих систем [2].

В умовах цифровізації кожен роботодавець зацікавлений у сучасних кваліфікованих кадрах. В свою чергу, кожен фахівець аграрного сектору зацікавлений у підтримці та зростанні власного рівня професійної компетентності на ринку праці. Таким чином, сучасна аграрна освіта має надавати можливості проходити 3 певною періодичністю (наприклад, 2-5 років) навчання за програмами підвищення кваліфікації, стажування або професійної перепідготовки, а також забезпечити доступ до навчальних матеріалів та думок експертів. Аграрні навчальні заклади усіх рівнів мають відповідати сучасним вимогам підготовки digital-фахівців. Найважливіша задача аграрної освіти в сучасних умовах - це підготовка digital-аграріїв, які здатні здійснити цифрову трансформацію аграрного сектору завдяки впровадженню цифрових технологій i платформних рішень для забезпечення технологічного прориву в аграрному секторі та досягнення зростання продуктивності праці [4].

Сучасні процеси діджиталізації, навіть за умови їх стримання суспільством, набиратимуть прискорення i досягнуть тієї межі, коли для підтримки світової системи аграрного виробництва кількох мільйонів цифрових 
професіоналів.

Отже, більш-менш швидкими темпами відбуватиметься скорочення доступних робочих місць в аграрному секторі, поява цілого класу вже непотрібних працівників, глобальне перепрофілювання персоналу, порушення механізму соціальних гарантій, у тому числі гідної пенсії по віку, соціального захисту тощо.

Цей клас безробітних вже має освіту, яка 3 року в рік втрачає свою актуальність разом із діджиталізацією виробництва та суспільства. У зв'язку із глобальними цифровими змінами, їх навички більше не потрібні, а нові вакансії вимагають знань i навичок, якими ці люди просто не володіють. Але найважливіше - у людей, звільнених 3 робочих місць, які орієнтовані на виконання рутинних завдань, немає головних для "нової реальності" навичок адаптивності. Проблема, яка виникає під час зникнення купи професій з ринку праці, полягатиме не лише у втраті джерела доходу, але й у втраті життєвих орієнтирів. Мета сучасної освіти - зробити цих людей конкурентоспроможними на ринку праці.

Висновки. Орієнтація на зміни в управлінні кадровим потенціалом в цифровій економіці змінюе практику роботи по прийняттю управлінських рішень. Особливо це стосується освітньої сфери, так як навчальні заклади здатні сприяти соціально-економічному розвитку, тобто бути центрами іноваційного розвитку. Цифрова трансформація освітньої галузі та формування вітчизняного інформаційно-освітнього середовища призведе до підвищення інтелектуальних, творчих здібностей учнів і вдосконалення професійних компетенцій педагогічних працівників, забезпечить широкий доступ до інноваційних освітніх технологій, підвищить інформаційну безпеку в мережах передачі даних.

\section{Лimepamypa:}

1. Базаров Р. Политическая карта мирового киберпространства Режим доступу : offline.cio-world.ru/2006/49/273982.

2. Ватковська М. Г. Англо-американський досвід упровадження електронного урядування в галузі освіти. Держава та регіони: наук.-виробн. Журн. Сер. :Державне управління, 2013. № 4(44). С. $13-18$.

3. Застрожнікова I.В. Вплив діджиталізації на кадрову політику в аграрному секторі. Інвестиції: практика та досвід. 2021. № 4. С. 77-81.

4. Застрожнікова I.В. Державне регулювання підготовки кадрів для об'єднаних територіальних громад вищими навчальними закладами України. Актуальні проблеми державного управління: зб. наук.пр. ХарРІ НАДУ «Магістр», 2019. Вип. 1 (55).

\section{References:}

1. Bazarov, R. (2006). Politicheskaya karta mirovogo kiber-prostranstva [Political map of the world cyber space]. Chief Information Officer - rukovoditel informatsionnoy sluzhby - Information Officer - head of the information service, 6, 124-126. Retrieved from offline.cioworld.ru/2006/49/273982 [in Russian].

2. Vatkovska, M. H. (2013). Anhlo-amerykanskyi dosvid uprovadzhennia elektronnoho uriaduvannia v haluzi osvity [The English-American experience of introduction of e-government in the field of education]. Derzhava ta rehiony: nauk.-vyrobn. Zhurn. Ser.: Derzhavne upravlinnia - 
States and regions: scientific-production journal. Series: Public Administration, 4(44), 13-18 [in Ukrainian].

3. Zastrozhnikova, I.V. (2021). Vplyv didzhytalizatsii na kadrovu polityku v ahrarnomu sektori [The impact of digitalization on human resources policy in the agricultural sector]. Investytsiyi: praktyka ta dosvid - Investments: practice and experience, 4, [in Ukrainian].

4. Zastrozhnikova, I. V. (2019). Derzhavne rehuliuvannia pidhotovky kadriv dlia obiednanykh terytorialnykh hromad vyshchymy navchalnymy zakladamy Ukrainy [State regulation of training for united territorial communities by higher educational establishments of Ukraine]. Aktualni problemyderzhavnoho upravlinnia - Actual Problems of Public Administration, 1 (55) [in Ukrainian]. 